\title{
A MULTINOMIAL LOGIT MODEL FOR ESTIMATING THE INFLUENCE OF HOUSEHOLD CHARACTERISTICS ON MOTORCYCLE OWNERSHIP: A Case Study in Denpasar City, Bali
}

\author{
by D. M. Priyantha Wedagama ${ }^{1}$
}

\begin{abstract}
This study investigates on household factors which influence motorcycle ownership in Denpasar city, Bali by using a multinomial logit model. The analyses show that the number of family members were about 0.83 and 2.6 times more likely to own, respectively, two and three motorcycles or more than one motorcycle. Total household income of less than one million rupiahs and between one and two million rupiahs were respectively 83.7 and 84.7 percents less likely to influence three motorcycles or more than one motorcycle ownership. Meanwhile, due to its high maneuverability on the congested road, a household was about 3.3 times more likely to own three motorcycles or more than one motorcycle. The probability analyses present that a double change in number of family member could influence one, two, and three motorcycles ownership or more by 19,34 , and 48 percents, respectively.
\end{abstract}

KEYWORDS: household characteristics, motorcycle ownership, multinomial logit.

\section{INTRODUCTION}

Motorcycle is the most favorite mode of transport in several cities in Indonesia including the city of Denpasar in Bali Province. Due to the small size and the engine capacity of 100-150cc, motorcycles have higher mobility, particularly on the congested road. People use motorcycles for either short or long distance trips over many trip purposes including work, shopping, leisure, and education. There are two main reasons for this situation, firstly poor services of the existing public transport and secondly motorcycle is more practical to cope with traffic congestion and more efficient compared to either private cars or public transport.

The numbers of motorcycles registered in Bali annually are almost 85 percent of the total vehicles with an average annual growth rate of approximately 11 percent. In 2007 there were 1,166,694 motorcycles in Bali among the 1,377,352 total vehicles registered. ${ }^{1}$ In the capital city of Denpasar, the number of registered motorcycles in 2007 was 390,000 of the total of 457,000 registered vehicles. During the daytime on weekdays, number of vehicles would be doubled about 800,000 units considering commuters and students trips to and from Denpasar. $^{2}$

There are three main modes in Bali that include private cars, heavy vehicles (bus and truck) and motorcycles, and they share together the roadways including on arterial roads. This generates a variety of conflicts amongst three modes above are quite frequently. Moreover, motorcyclists' behavior such as speeding and maneuvering in highly congested traffic conditions is not particularly favorable for other vehicles.

${ }^{1}$ Lecturer, Department of Civil Engineering, Faculty of Engineering, University of Udayana, Bukit Jimbaran , Badung - Bali, Indonesia 80361.

Note. The manuscript for this paper was submitted for review and possible publication on June 1, 2009; approved on October 26, 2009. Discussion open until February 2010. This paper is part of the ITS Journal of Civil Engineering, Vol. 29, No.1, May 2009. (C) ITS Journal of Civil Engineering, ISSN 2086-1206/2009.
This may lead to high proportion of motorcycle accidents and injuries. In fact, during period 2003-2007 there were 4,489 road accidents in Bali. Of these road accidents, on average 70 percent involved motorcycles. ${ }^{3}$ Despite the fact that high proportion in motorcycle accidents, motorcycle ownership in Bali province including in the capital city of Denpasar remains high. During the period of 2003-2006, motorcycle ownership in the city of Denpasar increased by 37 percent. $^{2}$

The high number of motorcycle ownership as well as motorcycle accident indicates the importance of a study focused on motorcycle particularly in developing countries. Therefore, a study on motorcycle ownership based on local household characteristics is essential in present and future study of mode choices. Within a local boundary, a study on motorcycle is required in order to identify solution and regulation concerning motorcycle in the traffic system, while a study on mode choice analyses a mode shift to/from motorcycle and its effect on the road network. ${ }^{4}$

This paper aimed at investigating on motorcycle ownership in the city of Denpasar, Bali with a disaggregate choice model using a Multinomial Logit Model. The model is developed to analyze local household factors which influence on motorcycle ownership. The model results would identify motorcycle ownership pattern which could be used as an input for a future travel demand forecasting.

Factors influencing motor vehicle ownership including motorcycle ownership differ from one country to another. This is particularly concerned with the local traffic system and total income. In theory, there has not been a standard to determine a motor vehicle ownership. However, due to limited references on this subject, several important factors that may influence motorcycle ownership were also considered from previous studies conducted in Taiwan and Malaysia. Indonesia and those two countries similarly have a high motorcycle ownership per 1000 population. ${ }^{4-6}$ This condition rarely happened in western countries where motorcycle ownership was very low. 


\section{Previous Studies}

A study has been conducted in Taipei (Taiwan) investigating on car and motorcycle ownerships with 336 samples using multinomial logit model. ${ }^{5}$ This study is based on the assumption that when both a car and a motorcycle owned by the household, each will have a relation of substitution. The study concluded that the main reason for motorcycle and car ownerships was not cost, but utility factors. The increase in reliability as well as convenience of a car may increase car ownership and reduce motorcycle ownership. The increase of both reliability and convenience of a car may increase car ownership between 12-29 percent.

Another study which also conducted in Taiwan used Poisson regression to investigate on car and motorcycle ownerships characteristics in three different cities, namely Taipei, Taichung and Kaohsiung. ${ }^{6}$ The data is collected by household interviews for the three cities. There were 350, 200 and 194 household samples collected in Taipei, Taichung and Kaohsiung respectively. The study concluded that, in Taipei, due to the supply of Mass Rapid Transport (MRT), many people used public transportation instead of motorcycles and cars. As the result, in Taipei, both car and motorcycle ownerships were less than those motor vehicles ownerships in the other two cities. Meanwhile, income has different impact on car and motorcycle ownerships in the three cities. Income affected car ownership in Taipei and affected both car and motorcycle ownerships in Taichung. However, income has been found to have a negative influence on both motorcycle and car ownerships in Kaohsiung..

A previous study conducted in Penang, Malaysia using multinomial logit model to examine motorcycle ownership. ${ }^{4}$ The study found that total monthly household income, car ownership, total number of driving licenses in the household and number of household members influencing motorcycle ownership. In addition, motorcycle will remain as the main mode of transport in the near future, particularly in the group of low and middle income households.

A study investigating on motor vehicle ownership characteristics was conducted in Indonesia. ${ }^{7}$ More specifically, the study focused on the influence of wealth level on motor vehicle ownership at municipality and regency levels. The wealth level was represented by the Gross Regional Domestic Product (GRDP). The data was collected in several provinces in Indonesia and analyzed using linear regression. The predictors were per capita GRDP as a 1993 prices, consumer price index (using 1988/1989 base years), ratio between minimum physical needs and minimum regional wage, population density per $\mathrm{km}^{2}$ area, road length (km per $1000 \mathrm{~km}^{2}$ area), number of bus seats per 1000 population, average ground elevation $(\mathrm{m})$, yearly rainfall $(\mathrm{mm})$ while the dependent variables were car and motorcycle ownerships rates at municipality and regency levels.

The study concluded that the GRDP at municipality level was more likely to influence motor vehicles (car and motorcycle) than at regency level. This may due to the fact that there have been a discrepancy of road network development between urban and rural areas.

\section{Multinomial Logit Model}

The objective of the Multinomial Logit (MNL) model is to estimate a function that determines outcome probabilities. This study uses MNL model to investigate the relationships that exist between household factors and motorcycle ownership (one, two and three motorcycles or more) in the city of Denpasar, Bali. The probability of a motorcycle ownership is restricted to lie between zero and one. One ownership category is chosen as the reference category, typically the first, the last or the value with the lowest or the highest frequency.

The probability of each category is compared to the probability of reference category. For categories $i=$ $2 \ldots . K$, the probability of categories are as follows: ${ }^{8}$

$$
\operatorname{Pr}(Y=i)=\frac{\exp \left(Z_{i}\right)}{1+\sum_{h=2}^{K} \exp \left(Z_{h i}\right)}
$$

Where:

$$
\alpha_{i}+\sum_{h=1}^{H} \beta_{i h} X_{i h}=Z_{i}
$$

For the reference category,

$$
\operatorname{Pr}(Y=1)=\frac{1}{1+\sum_{h=2}^{K} \exp \left(Z_{h i}\right)}
$$

After rearranging equation (1) and (2), the MNL model can be written as follows:

$$
\operatorname{Ln} \frac{P(Y=i)}{P(Y=1)}=\alpha_{i}+\sum_{h=1}^{H} \beta_{i h} X_{i h}=Z_{i}
$$

Where:

$$
\begin{array}{cl}
i & \text { the number of ownership categories } \\
\beta_{i h}{ }{ }_{i h} & \begin{array}{l}
\text { vectors of the estimated parameters and } \\
\text { predictor variables respectively }
\end{array} \\
\frac{P(Y=i)}{P(Y=1)} & \begin{array}{l}
\text { the probability of each categories with } \\
\text { the first category as reference. }
\end{array}
\end{array}
$$

The equation above expressed the logit (log odds) as a liner function of the independent factors $\left(X_{s}\right)$. Therefore, equation (3) allows for the interpretation of the logit weights for variables in the same way as in linear regressions.

\section{CASE STUDY AREA AND DATA DESCRIPTION}

\section{Case Study Area}

Province of Bali has an area of 5,634.40 $\mathrm{km}^{2}$ with the population is about 3.4 million. The island is widely known as a tourist destination. Most of popular tourist destinations are located in southern areas including Kuta, Sanur, and Nusa Dua. 


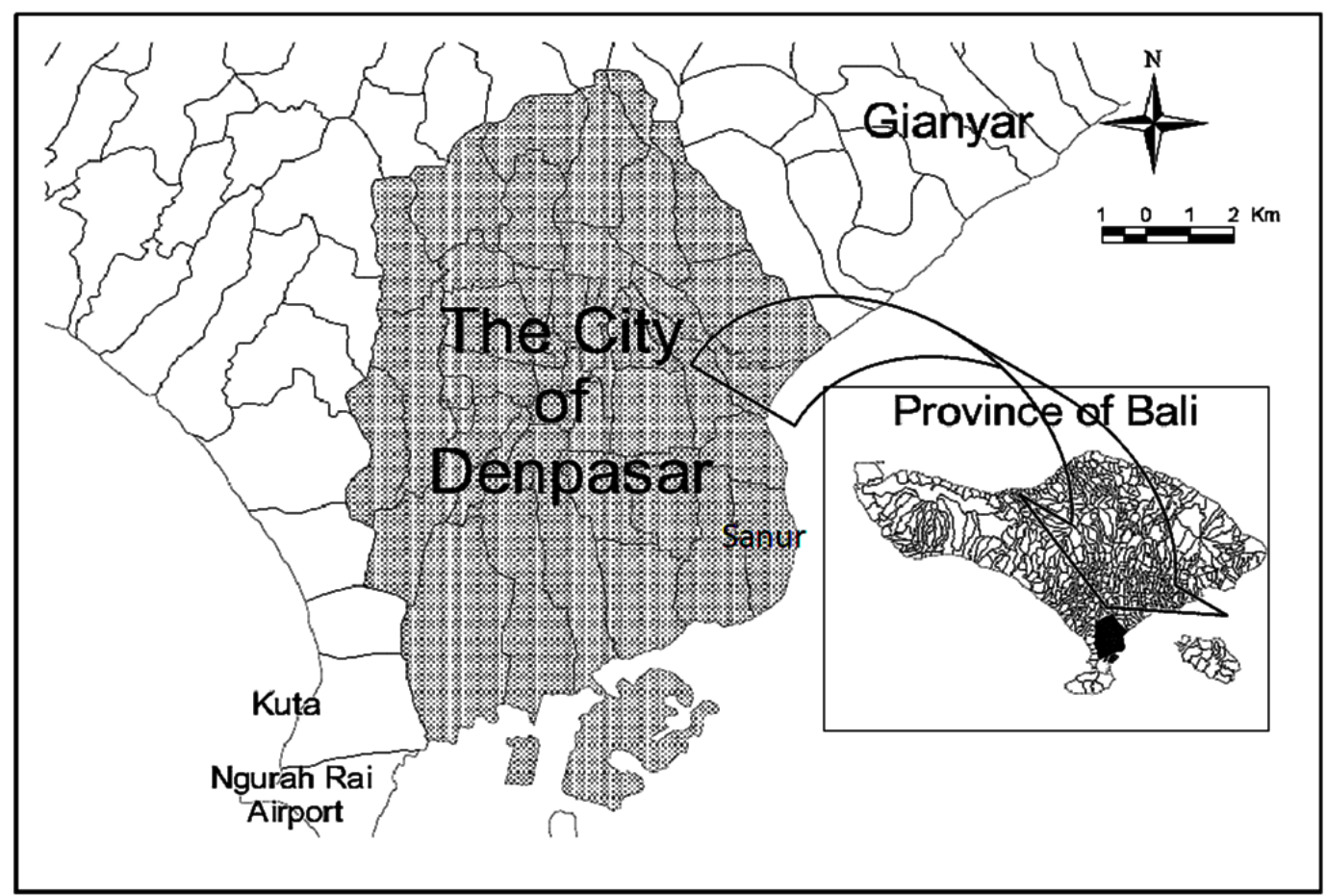

Fig. 1. Case Study Area - The City of Denpasar

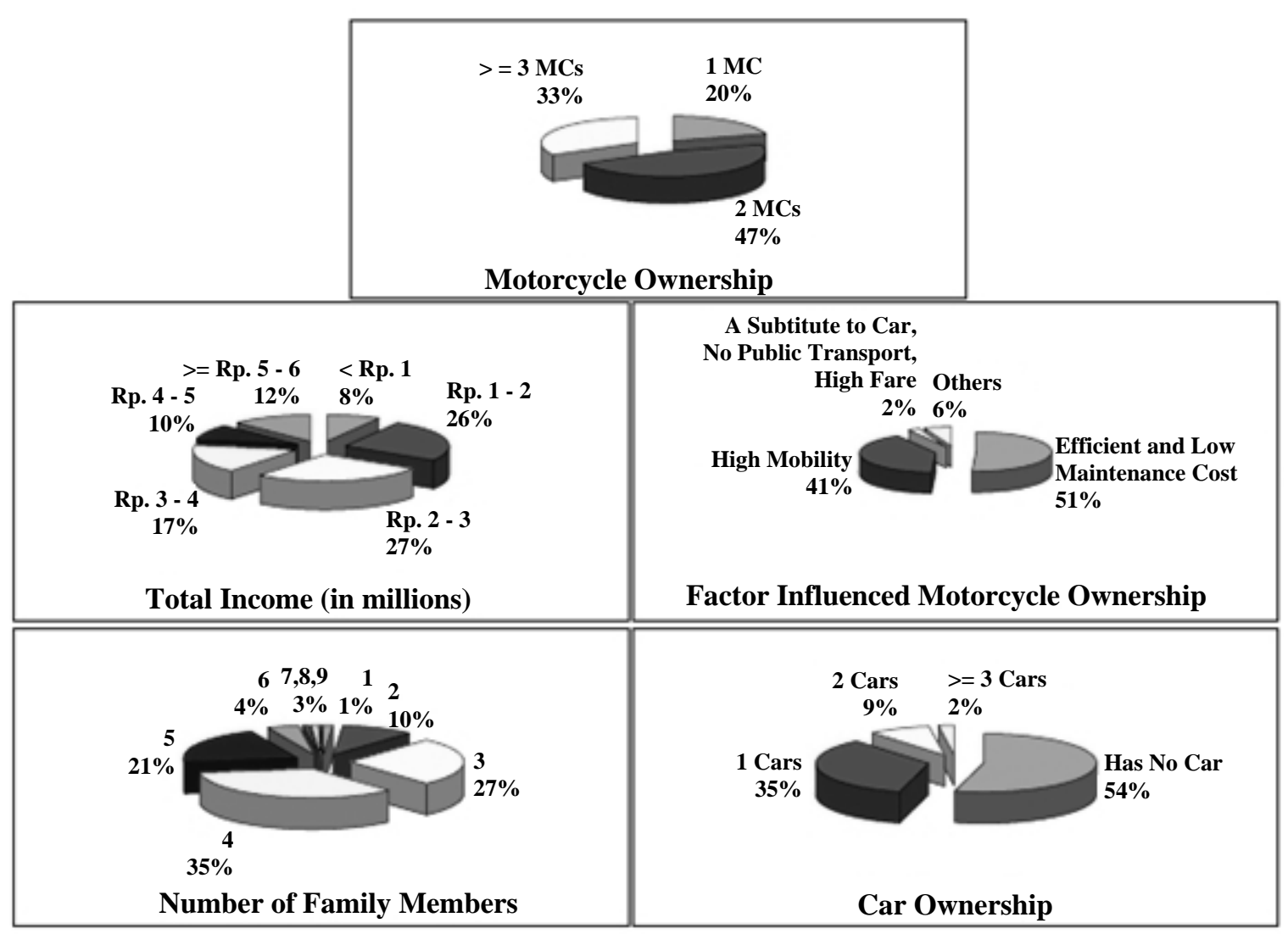

Fig. 2. Factors Influence Motorcycle Ownership in the City of Denpasar

Therefore, these areas are the most densely populated areas than the other parts of Bali. The capital city Denpasar as shown in Fig. 1 is also located in the Southern Bali. It has an area of $127 \mathrm{~km}^{2}$ with the population of $608,595 .^{1}$

\section{Data Description}

The study variables were based on local household characteristics in the city of Denpasar and several previous studies. ${ }^{4-6}$ The variables including income, factors influencing motorcycle ownership, numbers of family members and cars at the households were used as the reference for primary data collection. 
The questionnaires were distributed with the stratified random sampling technique for the households which own motorcycle in the city of Denpasar, and 313 samples were collected. The results were shown in Fig. 2.

Based on the questionnaires, about 20, 47, and 33 percent of the households own 1, 2 and 3 motorcycles or more respectively. In terms of number of family members, about $10,27,35,21$, and 7 percent of the household have 2, 3, 4, 5 and more than 5 members respectively Meanwhile, about 54 percent of the households have no car and about 53 percent of the household have total income between 1 and 3 million rupiahs per month. For the reference, the cheapest price for a new car is about 100 million rupiahs and for a new motorcycle is about 12 million rupiahs.

The questionnaires also show that about 51 percent of the households own motorcycle because it is efficient and low maintenance costs, 2 percent is the mixture of motorcycle as a substitute to car, no access to public transport and high public transport fare, 6 percent of those because of others and about 41 percent of those because it has a high mobility on the congested road and in passing the alley (narrow road).

\section{MODEL DEVELOPMENT}

Response variable is variable 1 , namely motorcycle, which is nominal in nature. Independent (predictors) variables including income and factors influencing motorcycle ownership were categorical, but numbers of family members and cars at the households were continuous variables. Categorical variables were represented using dummy variables following the coding system in SPSS, software used in this study. Study variables and their codes are shown in Table 1.

Considering the data proportion shown in Table 2, some predictor variables can be eliminated because of their small proportion. This is carried out by the hypothesis testing technique for proportions to decide whether a classification could be reduced. ${ }^{9}$ The following typical test was used:

$$
\begin{aligned}
& H_{0}: p_{i}=0 \\
& H_{a}: P_{i} \neq 0
\end{aligned}
$$

Where:

$$
\begin{aligned}
H_{0} & =\text { Null hypothesis } \\
H_{a} & =\text { Alternate hypothesis } \\
P_{i} & =\text { the proportion of a variable. }
\end{aligned}
$$

Based on the test, only one variable that is FIMC3 (a substitute to car, no public transport, high public transport fares) was eliminated from the model development stage.

The backward elimination process of multinomial logistic regression was followed using SPSS ver.15. All of reduced variables were selected using Likelihood Ratio( $L R)$ Chi-Square test calculated by $-2[L$ (null model) $-L$ (fitted model) $]$. Each variable that gives the value of $L R$ test more or equal to the value $L R$ test when all variables included were eliminated from the model. ${ }^{9}$ As a result, 3 variables were excluded from the model as shown in Table 3.

In order to assess the model goodness of fit, the pseudo $R^{2}$ is examined. It has been mentioned that in multinomial choice models, the higher pseudo $R^{2}$, the better the model. ${ }^{8}$ However, this is not always true. It has been stated that it is usual practice to ignore such measures because there is no general accepted measures for these types of models and have empirical and theoritical upper limits which are sometimes substantially less than one. ${ }^{10}$ Instead, measures to determine the model accuracy are presented below.

The presence of the relationship between the

\begin{tabular}{|c|c|c|}
\hline No & Description & Variable Name and Coding \\
\hline \multirow[t]{3}{*}{1.} & \multirow[t]{3}{*}{ Motorcycle ownership } & Motorcycle $=1$ (1 motorcycle owned by the household) \\
\hline & & Motorcycle $=2$ (2 motorcycles owned by the household $)$ \\
\hline & & Motorcycle $=3$ (3 motorcycles or more owned by the household) \\
\hline 2. & Numbers of family members & FamilyNo \\
\hline 3. & $\begin{array}{l}\text { Number of cars owned by the } \\
\text { household }\end{array}$ & Car \\
\hline \multirow[t]{6}{*}{4.} & \multirow[t]{6}{*}{ Total household income per month } & Income $=0$ (total income $<1$ million rupiahs) \\
\hline & & Income $=1$ ( $1 \leq$ total income $<2$ million rupiahs $)$ \\
\hline & & Income $=2$ ( $2 \leq$ total income $<3$ million rupiahs $)$ \\
\hline & & Income $=3$ ( $3 \leq$ total income $<4$ million rupiahs $)$ \\
\hline & & Income $=4$ ( $4 \leq$ total income $<5$ million rupiahs $)$ \\
\hline & & Income $=5$ (total income $\geq 5$ million rupiahs) \\
\hline \multirow[t]{4}{*}{5.} & \multirow{4}{*}{$\begin{array}{l}\text { Factors influencing motorcycle } \\
\text { ownership }\end{array}$} & FIMC0 $=$ more efficient and low maintenance costs $(1=$ yes, $2=$ no $)$ \\
\hline & & FIMC1 = higher mobility on the congested road (1=yes, $2=$ no) \\
\hline & & FIMC2 = others $(1=$ yes, 2 = no $)$ \\
\hline & & $\begin{array}{l}\text { FIMC3 = a substitute to car, no public transport, high public transport } \\
\text { fare }(1=\text { yes, } 2=\text { no })\end{array}$ \\
\hline
\end{tabular}
dependent variable and combination of independent variables are based on the statistical significance of the final model chi-square based on Table $4 .^{8}$

Table 1. Study Variables 
Table 2. Hypothesis Testing

\begin{tabular}{|c|c|c|c|c|c|}
\hline \multirow{2}{*}{ Description } & \multirow{2}{*}{$X$} & \multirow{2}{*}{$N$} & \multirow{2}{*}{$P$-Value } & \multicolumn{2}{|c|}{ 95\% Confidence Interval } \\
\hline & & & & Lower & Upper \\
\hline \multicolumn{6}{|l|}{ Total Household Income per Month } \\
\hline Total income $<1$ million rupiahs & 26 & 313 & 0.08 & 0.1 & 0.1 \\
\hline $1 \leq$ total income $<2$ million rupiahs & 80 & 313 & 0.26 & 0.2 & 0.3 \\
\hline $2 \leq$ total income $<3$ million rupiahs & 84 & 313 & 0.27 & 0.2 & 0.3 \\
\hline $3 \leq$ total income $<4$ million rupiahs & 54 & 313 & 0.17 & 0.1 & 0.2 \\
\hline $4 \leq$ total income $<5$ million rupiahs & 30 & 313 & 0.10 & 0.1 & 0.1 \\
\hline Total income $\geq 5$ million rupiahs & 39 & 313 & 0.12 & 0.1 & 0.2 \\
\hline \multicolumn{6}{|l|}{ Factors Influencing Motorcycle Ownership } \\
\hline Efficient and Low Maintenance Cost & 306 & 313 & 0.98 & 1.0 & 1.0 \\
\hline Higher Mobility on the Congested Road & 246 & 313 & 0.79 & 0.7 & 0.8 \\
\hline Others & 35 & 313 & 0.11 & 0.1 & 0.1 \\
\hline $\begin{array}{l}\text { A Substitute to Car, No Public Transport, } \\
\text { High Public Transport Fares * }\end{array}$ & 14 & 313 & 0.04 & 0.0 & 0.1 \\
\hline \multicolumn{6}{|c|}{$\begin{array}{l}\text { Note } \\
\text { * Statistically insignificant at the } 5 \text { percent level (the } 95 \text { percent confidence limits include } 0 \text { ) } \\
\text { Respondents were allowed answering more than } 1 \text { factors which influence motorcycle ownership } \\
X=\text { number of occurrence (yes }=1 \text { ) } \\
N=\text { sample size }\end{array}$} \\
\hline
\end{tabular}

Table 3. Variable Elimination

\begin{tabular}{|c|c|c|c|c|c|c|}
\hline \multirow{2}{*}{ Model } & \multirow{2}{*}{ Action } & \multirow{2}{*}{ Effect(s) } & Model Fitting Criteria & \multicolumn{3}{|c|}{ Effect Selection Tests } \\
\hline & & & -2 Log Likelihood & Chi-Square(a) & $\mathrm{df}$ & Sig. \\
\hline 0 & Entered & $<$ all $>$ (b) & 353.886 & 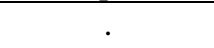 & & \\
\hline 1 & Removed & FIMC0 & 354.329 & .443 & 2 & .801 \\
\hline 2 & Removed & FIMC2 & 355.736 & 1.407 & 2 & .495 \\
\hline 3 & Removed & Car & 358.260 & 2.524 & 2 & .283 \\
\hline \multicolumn{7}{|l|}{ Where : } \\
\hline Car & : Number & wned by $\mathrm{t}$ & household & & & \\
\hline FIMC0 & : Motorcycl & re efficien & nd low maintenance costs & & & \\
\hline FIMC2 & : Motorcyc & ership due $t$ & ther factors & & & \\
\hline
\end{tabular}

In this analysis, the probability of the model chi-square (78.098) was 0.000 , less than or equal to the level of significance of 0.05 . The null hypothesis is that there was no difference between the model without independent variables and the model with independent variables was rejected. The existence of a relationship between the independent variables and the dependent variable was supported.

The classification accuracy rate typically should be 25 percent or more, higher than the proportional by chance accuracy rate. The proportional by chance accuracy rate was computed by calculating the proportion of each ownership category. It was computed by summing $0.201^{2}$ $+0.466^{2}+0.332^{2}$ which is equal to 0.368 (37 percent). The overall classification accuracy rate was 53.7 percent which was greater than the proportional by chance accuracy criteria of 46.25 percent $(1.25 \times 37.0$ percent $)$. Therefore, the criteria of classification accuracy is satisfied (refer Table 4).

\section{RESULTS AND DISCUSSIONS}

Table 5 shows the model results and the statistically significant predictor variables obtained from the analysis.
Multicollinearity was not present in the model as no standard errors (Std. Error) of coefficient $\beta$ has value more than 2. ${ }^{8}$ Further, discussions are focused on motorcycle ownership related factors which have 95 percent significance or more based on the model results.

In this study, the dependent variable is household motorcycle ownership (1, 2 and 3 motorcycles or more). One motorcycle owned by the household is considered as the reference or the base category. Estimated coefficients measure the change in the logit for a one-unit change in the predictor variable while keeping the other predictor variables constant. A positively estimated coefficient implies an increase in the likelihood that 2 or 3 motorcycles ownership or more will happen. A negative estimated coefficient indicates that there is less likelihood that 2 or 3 motorcycles ownership or more will happen.

P-value indicates whether or not a change in the predictor significantly changes the logit at the acceptance level. If p-value is greater than the accepted confidence level, then there is insufficient evidence that a change in the predictor affects the response category with respect to the reference category.

Based on Table 5, it was shown that significant predictor variables at 95 percent including numbers of 
Table 4. Model Summary

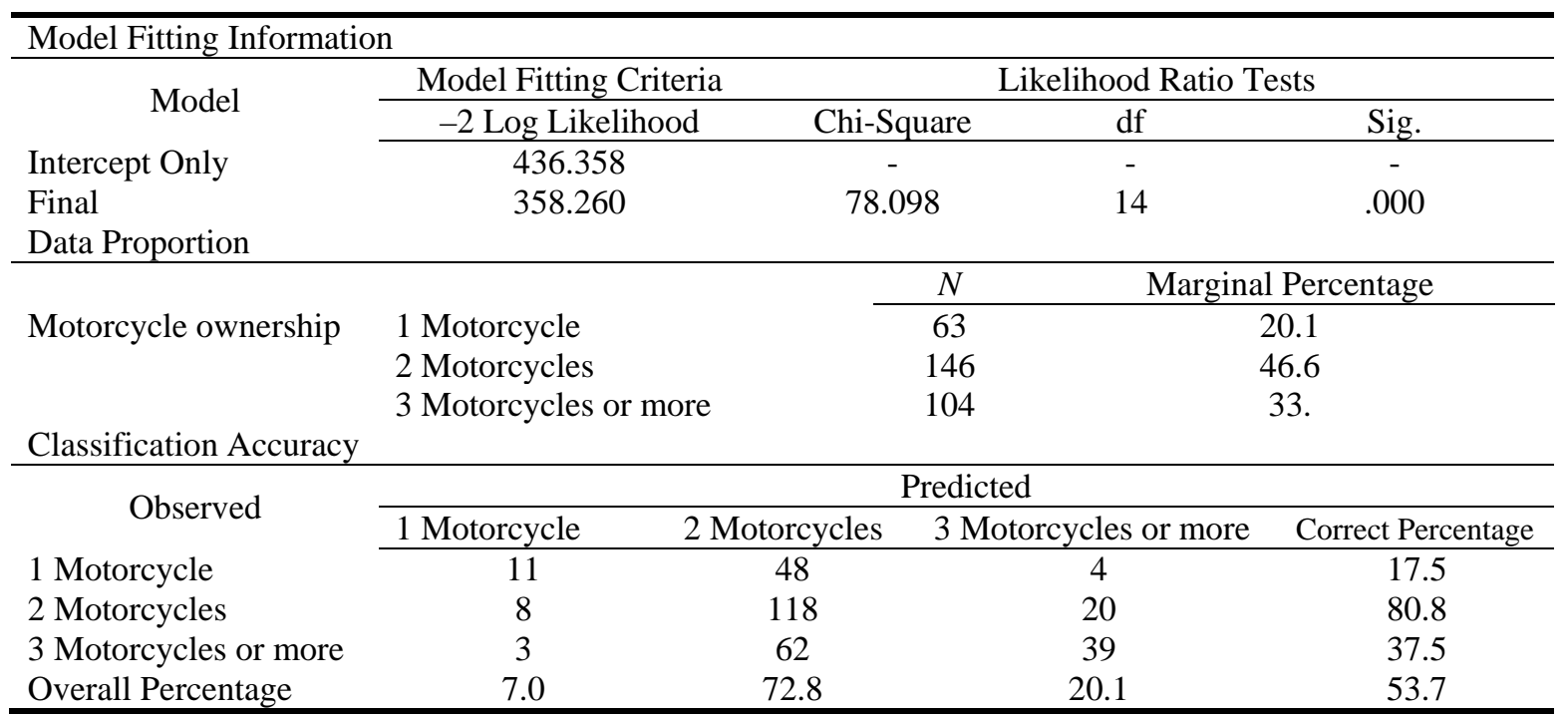

Table 5. Model Results

\begin{tabular}{|c|c|c|c|c|c|}
\hline \multicolumn{2}{|c|}{ Motorcycle Ownership(a) } & \multirow{2}{*}{$\begin{array}{l}\beta \\
-1.797\end{array}$} & \multirow{2}{*}{$\begin{array}{r}\text { Std. Error } \\
1.005\end{array}$} & \multirow{2}{*}{$\begin{array}{l}\text { Sig. } \\
.074\end{array}$} & \multirow[t]{2}{*}{$\overline{\operatorname{Exp}(\beta)}$} \\
\hline \multirow{9}{*}{2 motorcycles } & Intercept & & & & \\
\hline & {$[$ Income $=0]$} & -.731 & .859 & .394 & .481 \\
\hline & [Income $=1]$ & .197 & .765 & .796 & 1.218 \\
\hline & [Income=2] & .005 & .766 & .995 & 1.005 \\
\hline & [Income=3] & .310 & .815 & .703 & 1.364 \\
\hline & {$[$ Income $=4]$} & .474 & .911 & .603 & 1.607 \\
\hline & {$[$ Income $=5]$} & $0(\mathrm{~b})$ & . & & \\
\hline & [FIMC1=1] & .626 & .382 & .101 & 1.870 \\
\hline & [FIMC1=2] & 0(b) & & & \\
\hline \multirow{11}{*}{$\begin{array}{c}3 \text { motorcycles } \\
\text { or more }\end{array}$} & FamilyNo & .602 & .165 & .000 & 1.826 \\
\hline & Intercept & -2.824 & 1.076 & .009 & \\
\hline & {$[$ Income $=0]$} & -1.812 & .876 & .039 & .163 \\
\hline & [Income $=1]$ & -1.877 & .775 & .015 & .153 \\
\hline & [Income=2] & -1.265 & .749 & .091 & .282 \\
\hline & [Income=3] & -.769 & .799 & .335 & .463 \\
\hline & {$[$ Income $=4]$} & -.441 & .904 & .626 & .644 \\
\hline & [Income $=5]$ & 0 (b) & $v^{\prime}$ & & . \\
\hline & [FIMC1=1] & 1.189 & .450 & .008 & 3.285 \\
\hline & [FIMC1=2] & 0 (b) & & & \\
\hline & FamilyNo & .948 & .184 & .000 & 2.581 \\
\hline
\end{tabular}

a The reference category is: 1 Motorcycle.

b This parameter is set to zero because it is redundant.

family members (FamilyNo) on both categories 2 and 3 motorcycles ownership, while Income0, Income1 and FIMC1 were significant only for 3 motorcycles ownership or more category. Consequently, model interpretation will only be focused on these variables.

Based on Table 5, it was shown that significant predictor variables at 95 percent including numbers of family members (FamilyNo) on both categories 2 and 3 motorcycles ownership, while Income0, Income1 and FIMC1 were significant only for 3 motorcycles ownership or more category. Consequently, model interpretation will only be focused on these variables.
The value of $\operatorname{Exp}(\beta)$ for numbers of family members (FamilyNo) on 2 motorcycles ownership was 1.826 which implies that the odds increased by 83 percent (1.826 - 1.0 $=0.826$ ). Hence, numbers of family members were 83 percent more likely to influence 2 motorcycles than 1 motorcycle ownership. Meanwhile, numbers of family members were about 2.6 times more likely to influence 3 motorcycles or more than 1 motorcycle ownership. A previous study in Malaysia, ${ }^{6}$ however, has shown that the increase of family members decreased the likelihood of owning any motorcycles and preferred to purchase a car. In fact, it is much easier and cheaper for family members to purchase a motorcycle than a car in Indonesia. 
Table 5 also shows that total household income of less than 1 million rupiahs, between 1 and 2 million rupiahs were negatively related to 3 motorcycles ownership or more. They were 83.7 and 84.7 percent respectively less likely to influence 3 motorcycles or more than 1 motorcycle ownership. This is consistent with a study findings in Malaysia ${ }^{4}$ which also concluded that the lower income group will tend to purchase either one or two motorcycles.

Meanwhile, a factor of high mobility on the congested road were positively related to 3 motorcycles ownership or more. It was about 3.3 times more likely to influence 3 motorcycles or more than 1 motorcycle ownership. Thus, a high maneuverability on the congested road is considered as one of the utility factor of a motorcycle in Indonesia.

In order to analyze the motorcycle ownership probability, the log of the odds for 2 and 3 motorcycles ownership or more are calculated by multiplying the coefficients for the first and second group from the table of parameter estimates times the variables:

$$
\log \frac{P(2 \text { motorcycles })}{P(1 \text { motorcycle })}=-1.797-0.731 \text { income } 0
$$

+0.197income $1+0.005$ income $2+0.310$ income 3

\section{+0.474 income $4+0.626$ FIMC 1}

+0.602 FamilyNo

$\log \frac{P(\geq 3 \text { motorcycles })}{P(1 \text { motorcycle })}=-2.824-1.812$ income 0

-1.877income1-1.265income2 - 0.769income3

-0.441 income $4+1.189$ FIMC1 + 0.948FamilyNo

As shown in Table 5, obviously it was only number of family members affecting both motorcycle ownership groups at 95 percent level of confidence. Hence, the probability is determined by examining only for this variable. Based on the assumption that a 50 percent (half) change in number of family members, the variable probability is determined as follows:

$$
\begin{aligned}
& \log \frac{P(2 \text { motorcycles })}{P(1 \text { motorcycle })}=0.602 \times \text { FamilyNo }=0.602 \times 0.5=0.301 ; \\
& \log \frac{P(\geq \text { 3motorcycles })}{P(1 \text { motorcycle })}=0.948 \times \text { FamilyNo }=0.948 \times 0.5=0.474
\end{aligned}
$$

Having examined the log odds for each group, the probability of motorcycle ownership can be estimated as follows:

$$
\begin{aligned}
& P(\text { 1motorcycle })=\frac{e^{(0)}}{e^{(0,301)}+e^{(0,474)}+e^{(0)}}=0.253 \\
& P(2 \text { motorcycles })=\frac{e^{(0,301)}}{e^{(0,301)}+e^{(0,474)}+e^{(0)}}=0.341 ; \\
& P(\geq \text { 3motorcycles })=\frac{e^{(0,474)}}{e^{(0,301)}+e^{(0,474)}+e^{(0)}}=0.406
\end{aligned}
$$

where : $e^{(1 \text { motorcycle })}=e^{(0)}=1$.
As the results, a half change in number of family members will yield the probability of 1,2 and 3 motorcycles ownership or more by 25,34 , and 41 percent respectively. In addition, a 100 percent (doubled) change in number of family member will result in the probability of 1, 2 and 3 motorcycles ownership or more by 19, 34, and 48 percent respectively. This result indicates that the increase of family members will affect the growth of motorcycles in the future. In addition, the model result shows that the high mobility on congested road is a significant factor to influence 3 motorcycles ownership or more. Consequently, this will contribute more on road congestion and number of road accidents in the future.

Considering this study findings and a previous study in Taiwan, ${ }^{6}$ the local government should promote a mode shift from motorcycle to public transport. This only can be achieved with the public transportation development including improvement on the existing public transport and traffic management. It is expected that by providing cheap (compared to use a motorcycle), safe and comfort public transport, motorcycle ownership will be able to reduce.

\section{CONCLUSIONS}

This study investigates household factors which influence motorcycle ownership in the city of Denpasar, Bali using a multinomial logit model. The analyses show that numbers of family members were 83 percent more likely to influence two motorcycles than 1 motorcycle ownership and were about 2.6 times more likely to influence three motorcycles or more than one motorcycle ownership.

Meanwhile, total household income of less than 1 million rupiahs, between one and two million rupiahs were 83.7 and 84.7 percent respectively less likely to influence three motorcycles or more than one motorcycle ownership. On the other hand, the high mobility of motorcycle on the congested road was about 3.3 times more likely to influence three motorcycles or more than one motorcycle ownership.

The probability analyses present that a half changes in number of family members could influence one, two and three motorcycles ownership or more by 25, 34, and 41 percent respectively. In addition, a double change in number of family member could influence one, two and three motorcycles ownership or more by 19,34 , and 48 percent respectively.

\section{REFERENCES}

1. "Bali in Figures," Statistics of Bali Province, 2008.

2. "Denpasar in Figures," Statistics of The City of Denpasar, 2007.

3. “Accident Data Report," State Police of Bali Province, 2008.

4. Leong, L. V.; and Sadullah, A. F. M.,“A Study on The Motorcylce Ownership: A Case Study in Penang State, Malaysia”, Proceeding of the Eastern Asia Society for Transportation Studies, V. 6, Sep. 2007.

5. Hsu, T. P.; and Lin, Y. J.,"Multinomial Logit Model of Motorcycle and Car Ownership in Taiwan”, Proceeding of the Eastern Asia Society for Transportation Studies, V. 6, Sep. 2007. 
6. Hsu, T. P.; Tsai, C. C.; and Lin, Y. J.,“Comparative Analysis of Household Car and Motorcycle Ownership Characteristics", Proceeding of the Eastern Asia Society for Transportation Studies, V. 6, Sep. 2007.

7. Putranto, L. S.,“The Effect of Wealth Level on Indonesian Vehicle Ownership Rate", Universities Transport Study Group $35^{\text {th }}$ Annual Conference, Loughborough University, UK, Jan. 2003.

8. Washington, S. P.; Karlaftis, M. G.; and Mannering, F. L., "Statistical and Econometric Methods for Transportation Data Analysis”, Chapman \& Hall, USA, 2003.
9. Al-Ghamdi, A. S.,"Using Logistic Regression to Estimate the Influence of Accident Factors on Accident Severity”, Accident Analysis and Prevention, V. 34, pp, 729-741, 2002.

10. Donnel, C. J. O.; and Connor, D. H.,"Predicting The Severity of Motor Vehicle Accident Injuries Using Models of Ordered Multiple Choice", Accident Analysis and Prevention, V. 28, No.6, pp. 739 - 753, 1996. 